\title{
Activation of Mesangial Cells by the Phosphatase Inhibitor Vanadate Potential Implications for Diabetic Nephropathy
}

\author{
Ulrich O. Wenzel, Bruno Fouqueray, Purba Biswas, Giuseppe Grandaliano, Goutam Ghosh Choudhury, \\ and Hanna E. Abboud \\ Division of Nephrology, Department of Medicine, University Hospital and the Audie L. Murphy Veterans Affairs Hospital; \\ and The University of Texas Health Science Center at San Antonio, San Antonio, Texas 78284
}

\begin{abstract}
The metalion vanadate has insulin-like effects and has been advocated for use in humans as a therapeutic modality for diabetes mellitus. However, since vanadate is a tyrosine phosphatase inhibitor, it may result in undesirable activation of target cells. We studied the effect of vanadate on human mesangial cells, an important target in diabetic nephropathy. Vanadate stimulated DNA synthesis and PDGF $B$ chain gene expression. Vanadate also inhibited total tyrosine phosphatase activity and stimulated tyrosine phosphorylation of a set of cellular proteins. Two chemically and mechanistically dissimilar tyrosine kinase inhibitors, genistein and herbimycin A, blocked DNA synthesis induced by vanadate. Vanadate also stimulated phospholipase $C$ and protein kinase $\mathbf{C}$. Downregulation of protein kinase $\mathbf{C}$ abolished vanadate-induced DNA synthesis. Thus, vanadate-induced mitogenesis is dependent on tyrosine kinases and protein kinase $\mathbf{C}$ activation. The most likely mechanism for the effect of vanadate on these diverse processes involves the inhibition of cellular phosphotyrosine phosphatases. These studies demonstrating that vanadate activates mesangial cells may have major implications for the therapeutic potential of vanadate administration in diabetes. Although vanadate exerts beneficial insulin-like effects and potentiates the effect of insulin in sensitive tissue, it may result in undesirable activation of other target cells, such as mesangial cells. (J. Clin. Invest. 1995. 95:1244-1252.) Key words: plateletderived growth factor • human kidney $\bullet$ tyrosine phosphorylation • protein kinase $\mathrm{C} \cdot$ phospholipase $\mathrm{C}$
\end{abstract}

\section{Introduction}

The phosphatase inhibitor vanadate has insulin-like effects and corrects hyperglycemia in insulin-dependent and insulin-independent animal models of diabetes $(1,2)$. For these reasons, vanadate administration has been advocated as a therapeutic modality for diabetes. Vanadate has multiple biologic effects, including inhibition of $\left(\mathrm{Na}^{+} \mathrm{K}^{+}\right)$-ATPase and protein tyrosine

Address correspondence to Hanna E. Abboud, MD, Department of Medicine, Division of Nephrology, The University of Texas Health Science Center at San Antonio, 7703 Floyd Curl Drive, San Antonio, TX 782847882.

Received for publication 23 March 1994 and in revised form 14 October 1994.

The Journal of Clinical Investigation, Inc.

Volume 95, March 1995, 1244-1252 phosphatases (PTPases). ${ }^{1}$ Inhibition of tyrosine phosphatases is thought to represent one major mechanism by which vanadate mediates some of its biologic effects, including enhancement of insulin sensitivity (3). Renal and specifically glomerular injury is a major early feature of diabetic nephropathy. It is manifested as basement membrane thickening and expansion of the glomerular mesangium. This expansion consists primarily of matrix, but hypercellularity and hypertrophy of mesangial cells have recently been reported $(4,5)$. There is also increasing evidence that activation of mesangial cells plays a key role not only in diabetes, but also in other forms of acute and chronic glomerular injury in man as well as experimental animals (6).

The biologic effects of vanadate are very diverse, depending on the target cell and the concentration of vanadate. For example, vanadate induces angiogenesis and mitogenesis in some mesenchymal cells $(7-10)$, reverses differentiation of muscle cells mimicking fibroblast growth factor (11), prevents cell death of mouse embryo cells caused by growth factor deprivation (12), and stimulates hyaluronan synthesis in human mesothelial cells (13). Vanadate has been shown to activate certain signal transduction mechanisms. Since many of the signals that result in mesangial cell activation involve tyrosine phosphorylation, mesangial cells represent a potentially important target for vanadate. There are no data available that address the effect of vanadate on mesangial cells. In this study we explored the biologic effects of vanadate on mesangial cells and show that at low concentrations that inhibit PTPases, vanadate is a strong mitogen for human glomerular mesangial cells and induces PDGF B chain gene expression. This effect of vanadate was associated with enhanced tyrosine phosphorylation and sustained activation of phospholipase C (PLC) and protein kinase $\mathrm{C}$ (PKC). Furthermore, DNA synthesis induced by vanadate is dependent on tyrosine phosphorylation and PKC activation. Our in vitro findings may have major implications relevant to the use of vanadate in vivo in the diabetic state.

\section{Methods}

Materials. Tissue culture materials were obtained from Gibco (Grand Island, NY). Anti-phosphotyrosine antibody (IgG2bk) was purchased from UBI (Lake Placid, NY). Reagents for PKC assay were purchased as a kit from BRL (Grand Island, NY). Phorbol 12-myristate 13-acetate (PMA) and sodium orthovanadate were obtained from Sigma Chemical Co. (St. Louis, MO). A 1-mM stock solution of vanadate was prepared in PBS and stored at $4^{\circ} \mathrm{C}$. All other reagents were analytical grade.

1. Abbreviations used in this paper: $\mathrm{DAG}$, diacylglycerol; $\mathrm{IP}_{3}$, inositol 1,4,5-trisphosphate; MBP, myelin basic protein; PKC, protein kinase C; PLC, phospholipase C; PMA, phorbol 12-myristate 13-acetate; PTK, protein tyrosine kinase; PTPase, protein tyrosine phosphatase; RCML, reduced carboxymethylated and maleylated lysozyme. 
Mesangial cell cultures. Mesangial cell cultures were established from glomeruli isolated from human donor kidneys judged unsuitable for transplantation or normal portions of surgical nephrectomy samples. Mesangial cells were extensively characterized by electron microscopy and immunohistochemical staining as previously reported (14). Unless stated otherwise, cells were used between the 17th and 11th passages. To compare the response of early and late passaged cells to vanadate, selected experiments were also performed in early passaged cells from the same cell line (passage 3). Cells were maintained in Waymouth's medium supplemented with $15 \mathrm{mM}$ Hepes, $0.6 \mathrm{U} / \mathrm{ml}$ insulin, $2 \mathrm{mM}$ glutamine, $0.1 \mathrm{mM}$ nonessential amino acids, $1 \mathrm{mM}$ sodium pyruvate, antibiotic/antifungal solution, and $17 \%$ FBS. In some experiments and to determine whether glucose concentration influences the response of the cells to vanadate, cells were cultured in DME containing low ( 100 $\mathrm{mg} / \mathrm{dl})$ or high $(450 \mathrm{mg} / \mathrm{dl})$ glucose and the previously noted supplements, including FBS.

DNA synthesis. Cells were plated in 24-well dishes and incubated with Waymouth's medium containing $17 \%$ FBS until they became confluent. Cells were then made quiescent by incubation for $48 \mathrm{~h}$ in medium free of insulin and FBS. Vanadate was added, and after 24,48 , or $72 \mathrm{~h}$, cells were pulsed with $1 \mu \mathrm{Ci} / \mathrm{ml}\left[{ }^{3} \mathrm{H}\right]$ thymidine (New England Nuclear, Boston, MA) for $4 \mathrm{~h}$. At the end of the pulsing period, medium was removed, ice-cold 5\% TCA was added, and the dishes were kept on ice. After two more washes with 5\% TCA, cells were solubilized by adding $0.25 \mathrm{~N} \mathrm{NaOH}$ and $0.1 \%$ SDS. $0.5 \mathrm{ml}$ of this solubilized cell solution was then neutralized and counted in a scintillation counter. Two chemically and mechanistically dissimilar tyrosine kinase inhibitors, genistein (UBI) and herbimycin A (a kind gift of Dr. T. Yoneda, University of Texas Health Science Center, San Antonio, TX), were used to study the role of tyrosine phosphorylation in DNA synthesis. The isoflavone compound genistein is a competitive inhibitor with respect to ATP (15), whereas the benziquinonoid antibiotic herbimycin is thought to inhibit protein tyrosine kinase (PTK) activity through benziquinone interaction with protein sulf hydral groups (16). Quiescent cells were pretreated with the inhibitors before the addition of vanadate.

Autoradiography. The effect of vanadate on DNA synthesis was also determined by autoradiography of labeled nuclei as described (17). Mesangial cells were plated onto slides (Lab-Tek, Nunc, Inc., Naperville, IL) at a density of $1 \times 10^{4}$ cells per chamber in Waymouth's medium containing $17 \%$ FBS. Confluent cells were made quiescent by replacing the culture medium with serum-free medium for $48 \mathrm{~h}$. Vanadate was added for $24 \mathrm{~h}$ followed by pulsing for $4 \mathrm{~h}$ with $1 \mu \mathrm{Ci} / \mathrm{ml}$ $\left[{ }^{3} \mathrm{H}\right]$ thymidine. At the end of the pulsing period, an equal volume of freshly prepared 3:1 methanol/acetic acid fixative was added to the medium for $10 \mathrm{~min}$. This half-strength solution was then replaced by an equal volume of undiluted 3:1 methanol/acetic acid fixative. After $10 \mathrm{~min}$, cells were air dried and exposed to nuclear emulsion (NTB = 2, Eastman Kodak Co., Rochester, NY) for $3 \mathrm{~d}$ at $4^{\circ} \mathrm{C}$. The slides were then developed (Kodak D-19 developer), fixed (Kodak fixer), and stained with hematoxylin/eosin. The number of positive nuclei per microscopic field $(\times 100)$ was determined by examining $10-20$ fields per slide.

Cell counts. Cells were plated in 12-well dishes at subconfluent density in Waymouth's medium containing FBS. After cell attachment overnight, cells were washed with PBS and incubated with vanadate in serum-free medium. After $2 \mathrm{~d}$, the cultures were washed with PBS and harvested into $1 \mathrm{ml}$ of $0.05 \%$ trypsin-EDTA diluted in HBSS without calcium or magnesium. Cells were then resuspended in $1 \mathrm{ml}$ of complete medium containing $17 \%$ FBS to neutralize the trypsin and counted using a coulter counter (Coulter Electronics, Hialeah, FL).

RNA isolation and analysis by solution hybridization. Mesangial cells were harvested in guanidine thiocyanate buffer, and RNA was prepared on a cesium chloride gradient. Total RNA was quantitated by optical density, and integrity was confirmed by ethidium bromide staining of ribosomal RNA. A ribonuclease protection assay was used to determine PDGF B chain expression using a procedure described earlier (18). The DNA template was constructed by cloning a 960-bp BanIIBanII restriction fragment, encompassing portions of exons 6 and 7 of the c-sis gene, into the SmaI site of plasmid pT7-2 (United States Biochemical Corp., Cleveland, $\mathrm{OH}$ ). To generate the single-stranded ${ }^{32} \mathrm{P}$-labeled RNA probe, the plasmid was linearized and transcription was performed using the T7 RNA polymerase (Promega, Madison, WI) in the presence of $40 \mathrm{mM}$ Tris- $\mathrm{HCl}, \mathrm{pH} 7.5,6 \mathrm{mM} \mathrm{MgCl}, 10 \mathrm{mM}$ $\mathrm{NaCl}, 2 \mathrm{mM}$ spermidine, $40 \mathrm{mM}$ DTT, $40 \mathrm{U} / \mathrm{ml} \mathrm{RNasin,} 0.5 \mathrm{mM}$ each of ATP, GTP, and CTP, $12 \mu \mathrm{M}$ UTP, $50 \mu \mathrm{Ci}$ of [ ${ }^{32} \mathrm{P}$ ] UTP $(800 \mathrm{Ci}$ / mmol; Amersham, Arlington Heights, IL) at $37^{\circ} \mathrm{C}$ for $1 \mathrm{~h}$. This was followed by the addition of RNase-free DNase (Promega) and another 15-min incubation to remove any remaining DNA template. After repeated extraction with phenol/chloroform and precipitation in ethanol, the RNA pellet was resuspended in hybridization buffer consisting of $80 \%$ formamide. The labeled RNA probe $\left(10^{6} \mathrm{cpm}\right)$ was hybridized overnight at $55^{\circ} \mathrm{C}$ to $100 \mu \mathrm{g}$ of total RNA prepared from mesangial cells. After hybridization, the samples were digested with RNase A (50 $\mu \mathrm{g} / \mathrm{ml})$ and RNase $\mathrm{T} 1(2 \mu \mathrm{g} / \mathrm{ml})$ followed by the addition of proteinase $\mathrm{K}$ to inactivate the remaining RNase. After extraction in phenol/chloroform, the samples were precipitated twice in ethanol, redissolved in loading buffer containing $90 \%$ formamide, and separated on $6 \%$ polyacrylamide/urea gel. Gels were exposed to x-ray film (X-Omat, Kodak) with intensifying screens at $-70^{\circ} \mathrm{C}$.

Labeling of substrates and assay of PTPase activity. Myelin basic protein (MBP) and reduced carboxymethylated and maleylated lysozyme (RCML) (Sigma Chemical Co.) were labeled on tyrosine residues using $\left[\gamma-{ }^{32} \mathrm{P}\right]$ ATP (Du-Pont-New England Nuclear, Boston, MA) and p60 ${ }^{\text {c-src }}$ tyrosine kinase (Oncogene Science, Manhasset, NY) as described (19). $5 \mu \mathrm{g}$ of $\mathrm{MBP}$ or RCML was incubated at $30^{\circ} \mathrm{C}$ for 30 min with $2 \mathrm{U}$ of $\mathrm{p}^{\mathrm{c}-\mathrm{src}}$ and $20 \mu \mathrm{Ci}$ of $\left[\gamma^{-32} \mathrm{P}\right] \mathrm{ATP}$ in $50 \mathrm{mM}$ Hepes, $\mathrm{pH} 7.4,10 \mathrm{mM} \mathrm{MnCl}{ }_{2}$ buffer. The reaction was terminated by adding $0.12 \mathrm{ml}$ of $10 \%$ phosphoric acid, $0.5 \mathrm{ml}$ of $20 \%$ (wt/vol) TCA, $20 \mathrm{mM}$ $\mathrm{NaH}_{2} \mathrm{PO}_{4}$, and $0.04 \mathrm{ml}$ of $5 \mathrm{mg} / \mathrm{ml} \mathrm{BSA}$. After incubation on ice for $30 \mathrm{~min}$, the reaction mixture was centrifuged at $10,000 \mathrm{~g}$ for $3 \mathrm{~min}$. The protein precipitates were washed three times with $20 \%(\mathrm{wt} / \mathrm{vol})$ TCA, $20 \mathrm{mM} \mathrm{NaH}_{2} \mathrm{PO}_{4}$ and then dissolved in $0.2 \mathrm{M}$ Tris- $\mathrm{HCl}, \mathrm{pH} 8.0$. After vanadate stimulation, quiescent mesangial cells were washed twice with ice-cold PBS, homogenized in a lysis buffer $(250 \mathrm{mM}$ sucrose, 5 mM EDTA, $50 \mathrm{mM}$ Hepes, $\mathrm{pH}$ 7.4, $5 \mathrm{mM}$ benzamidine, $115 \mu \mathrm{M}$ PMSF, $0.05 \%$ aprotinin, $1 \%$ Triton $\mathrm{X}-100$ ), and centrifuged for $30 \mathrm{~min}$ at $4^{\circ} \mathrm{C}$ at $10,000 \mathrm{~g}$. The supernatant was stored frozen at $-70^{\circ} \mathrm{C}$ until assay. For phosphatase assay, $0.5 \mu \mathrm{g}$ of total cell lysate was assayed for PTPase activity in a total volume of $50 \mu \mathrm{l}$ containing $5 \mu \mathrm{l}$ of phosphatase buffer ( $25 \mathrm{mM}$ Hepes, pH 7.3, $5 \mathrm{mM}$ EDTA, $10 \mathrm{mM}$ DTT) in the presence of tyrosine-phosphorylated MBP or RCML $\left(2-4 \times 10^{4} \mathrm{cpm}\right)$. The reaction mixture was incubated at $30^{\circ} \mathrm{C}$ for $30 \mathrm{~min}$, and $0.75 \mathrm{ml}$ of charcoal acidic mixture $\left(0.9 \mathrm{M} \mathrm{HCl}, 2 \mathrm{mM} \mathrm{NaH} \mathrm{PO}_{4}, 4 \%\right.$ [wt/vol] Norit $\mathrm{A}$; Sigma Chemical Co.) was added to terminate the reaction. After centrifugation for $10 \mathrm{~min}$ at $10,000 \mathrm{~g}$, the free radioactivity in $0.4 \mathrm{ml}$ of supernatant was measured. Enzyme activity was expressed as a percentage of radioactivity released from the total phosphorylated substrate. Each sample was run in duplicate.

Western blot analysis. Quiescent cells were incubated with $7.5 \mu \mathrm{M}$ vanadate for $30 \mathrm{~min}$. The cells were then washed three times with icecold PBS and lysed in solubilization buffer $(20 \mathrm{mM}$ Tris- $\mathrm{HCl}, \mathrm{pH} 7.5$, $150 \mathrm{mM} \mathrm{NaCl}, 5 \mathrm{mM}$ EDTA, $1 \% \mathrm{NP}-40,1 \mathrm{mM} \mathrm{Na}_{3} \mathrm{VO}_{4}, 1 \mathrm{mM}$ PMSF, $0.25 \%$ aprotinin ) at $4^{\circ} \mathrm{C}$ for $30 \mathrm{~min}$. The soluble cell extract was centrifuged at $10,000 \mathrm{~g}$ for $30 \mathrm{~min}$. Protein concentration was determined by a protein reagent assay (Bio-Rad Laboratories, Richmond, CA). Equal amounts of untreated and vanadate-treated cell lysates were analyzed on $7.5 \%$-SDS gel. Separated proteins were transferred to nitrocellulose and immunoblotted with anti-phosphotyrosine mAb. The bound antibody was detected by ${ }^{125}$ I-protein A (20).

Analysis of inositol phosphates. Inositol phosphates were measured as described (21). Confluent mesangial cells in six-well dishes were placed in inositol-free, serum-free RPMI 1640 medium containing 3 $\mu \mathrm{Ci} / \mathrm{ml} \mathrm{2}\left[{ }^{3} \mathrm{H}\right]$ myoinositol (Amersham) for $48 \mathrm{~h}$. After a 15 -min preincubation with $15 \mathrm{mM} \mathrm{LiCl}$ at $37^{\circ} \mathrm{C}$, vanadate was added for different time periods. The incubation was terminated by quickly aspirating the medium and adding $2 \mathrm{ml}$ of ice-cold 5\% TCA. The cells were then 
scraped, and each well was rinsed with another $2 \mathrm{ml}$ of $5 \% \mathrm{TCA}$. The TCA was then removed by extracting the sample twice with diethyl ether. The samples were neutralized and loaded onto 2-ml anion exchange columns (AG1X8, Bio-Rad Laboratories). The columns were washed with $10 \mathrm{ml}$ of water and $10 \mathrm{ml}$ of $5 \mathrm{mM}$ sodium tetraborate. Inositol phosphates were then eluted with $10 \mathrm{ml}$ of increasing concentration of ammonium formate in $0.1 \mathrm{M}$ formic acid. Using this technique, ammonium inositol 1,4,5-trisphosphate $\left(\mathrm{IP}_{3}\right)$ elutes with $0.8 \mathrm{M}$ ammonium formate. $5 \mathrm{ml}$ of each collected fraction was mixed with scintillation fluid and counted in a beta counter.

Intracellular calcium measurement. Intracellular calcium was measured as described previously (21). Mesangial cells were plated onto $14 \times 14 \mathrm{~mm}$ plastic coverslips (Aclar, Proplastics, Linden, NY), placed in 12-well dishes, and grown in Waymouth's medium containing serum. Confluent cells were washed and placed in serum-free Waymouth's medium containing $0.2 \%$ BSA for $18 \mathrm{~h}$. The cells were loaded with fura- 2 by incubation for $50 \mathrm{~min}$ at $37^{\circ} \mathrm{C}$ in $1 \mathrm{ml}$ of serum-free medium containing $0.2 \%$ BSA, $5 \mu \mathrm{M}$ fura-2 acetoxymethylester (Molecular Probes, Eugene, OR), and $0.02 \%$ pluronic acid F127 (Molecular Probes). At the end of the loading period, the coverslips were washed with physiological salt solution $(150 \mathrm{mM} \mathrm{NaCl}, 5 \mathrm{mM} \mathrm{KCl}, 2 \mathrm{mM}$ $\mathrm{CaCl}_{2}, 1 \mathrm{mM} \mathrm{MgSO}{ }_{4}, 10 \mathrm{mM}$ Hepes, $10 \mathrm{mM}$ glucose) containing $0.2 \%$ BSA and kept in the same solution on ice until use; the cells were used within $2 \mathrm{~h}$ of loading. Coverslips were rapidly rinsed in physiological salt solution to remove any residual leaked dye and then placed diagonally in a square quartz cuvette so that the excitation and emission paths were at $45^{\circ}$ angles to the coverslip. The cuvette, containing $2.5 \mathrm{ml}$ of physiological salt solution, with its stirring device was placed in a thermostatically controlled chamber at $37^{\circ} \mathrm{C}$ in the Deltascan system I (PTI, New Brunswick, NJ). A 450-W xenon lamp was used as a light source. Excitation wavelengths were 340 and $380 \mathrm{~nm}$, and emitted light was collected at $510 \mathrm{~nm}$. Integration time was $0.1 \mathrm{~s}$ at each wavelength. Readings were collected using Delta-scan software (PTI). The 340/380 ratio was then processed as previously described (22) to determine the intracellular free calcium concentration. The $K_{\mathrm{d}}$ for fura 2 was assumed to be $224 \mathrm{nM}$. For each monolayer, the maximal fluorescence ratio was determined by lysing the cells with $0.5 \%$ Triton X-100, and the minimal fluorescence ratio was determined by the addition of $10 \mathrm{mM}$ EGTA.

$P K C$ assay. PKC assay was performed as previously described by us (23). Confluent mesangial cells were made quiescent by placing them in serum-free medium for $48 \mathrm{~h}$. Cells were incubated with $7.5 \mu \mathrm{M}$ vanadate for $15 \mathrm{~min}$. The cells were washed twice with PBS and lysed in homogenization buffer ( $20 \mathrm{mM}$ Tris- $\mathrm{HCl}, \mathrm{pH} 7.5,0.5 \mathrm{mM}$ EDTA, $0.5 \mathrm{mM}$ EGTA, $0.5 \%$ Triton X-100, $25 \mu \mathrm{g} / \mathrm{ml}$ aprotinin, $25 \mu \mathrm{g} / \mathrm{ml}$ leupeptin) at $4^{\circ} \mathrm{C}$. The cell lysate was centrifuged at $10,000 \mathrm{~g}$ for 30 min at $4^{\circ} \mathrm{C}$. PKC was partially purified using the DE-52 (DEAE) column. The protein concentration in the eluate was measured by the BioRad method. PKC activity was determined as described $(24,25)$ using reagents purchased as a kit (Gibco BRL, Gaithersburg, MD). The assay measures phosphotransferase activity to a synthetic peptide from MBP in the presence of phorbol ester, phosphatidylserine, and $\left[{ }^{32} \mathrm{P}\right]$ ATP. A pseudosubstrate inhibitor was used to determine the nonspecific activity. Phosphotransferase activity was expressed as pmoles of ${ }^{32} \mathrm{P}$ incorporated into the synthetic peptide per $5 \mathrm{~min}$. In experiments in which downregulation of PKC was performed, cells were incubated for $48 \mathrm{~h}$ with 0.6 $\mu \mathrm{M}$ PMA before the addition of vanadate.

Statistics. The significance of the data expressed as mean \pm SEM was analyzed by unpaired Student's $t$ test.

\section{Results}

Vanadate stimulates DNA synthesis and mesangial cell proliferation. Quiescent human mesangial cells in culture were assayed for their ability to incorporate $\left[{ }^{3} \mathrm{H}\right]$ thymidine into DNA after exposure to vanadate. Addition of different concentrations of vanadate ranging from 0.1 to $25 \mu \mathrm{M}$ to the cells stimulated thymidine incorporation, with a maximum effect obtained at 5 to $7.5 \mu \mathrm{M}$ (Fig. $1 a$ ). To characterize further the mitogenic effect of vanadate, the stimulation of DNA synthesis by vanadate was also confirmed by whole-cell autoradiography. The number of labeled nuclei after treatment of the quiescent cells with $7.5 \mu \mathrm{M}$ vanadate increased from $2.1 \pm 0.2$ to $29.2 \pm 1.7$ per microscopic field. Since cultured mesangial cells may undergo phenotypic modulation with increasing passage, we also tested the effect of vanadate on DNA synthesis in early passage cells. For these experiments, we used the same cell line that was used for the late passages. Frozen stocks of primary cultures were thawed, passaged, and used as passage 3. Similar to its effect on late passage cells, vanadate also stimulated $\left[{ }^{3} \mathrm{H}\right]$ thymidine incorporation in early passage mesangial cells, with a maximum effect obtained at $5 \mu \mathrm{M}$ (Fig. $1 b$ ). The mitogenic effect of vanadate in the early passage cells was further confirmed by whole-cell autoradiography. Treatment of early passage cells with $5 \mu \mathrm{M}$ vanadate increased the number of labeled nuclei from $4.40 \pm 0.87$ to $34.4 \pm 5.84(P<0.001)$ per microscopic field. Since the diabetic state is characterized by marked variation in glucose levels, we determined whether low and high glucose levels influence the induction of DNA synthesis by vanadate. For these experiments, mesangial cells were grown and passaged in DME containing low $(100 \mathrm{mg} / \mathrm{dl})$ or high (450 mg/dl) glucose concentration and made quiescent in the respective serum-free media. Vanadate caused an almost equal increase in $\left[{ }^{3} \mathrm{H}\right]$ thymidine incorporation in cells cultured under both conditions (Fig. 1, $c$ and $d$ ). Whole-cell autoradiography showed that vanadate $(5 \mu \mathrm{M})$ increased the number of labeled nuclei per microscopic field under low glucose conditions from $1.9 \pm 0.45$ to $16.3 \pm 2.03(P<0.001)$ and in cells cultured in medium containing high glucose from $0.78 \pm 0.19$ to $13.48 \pm 1.36$ $(P<0.001)$. These data indicate that vanadate stimulates DNA synthesis in mesangial cells under normoglycemic and hyperglycemic conditions. A significant increase in $\left[{ }^{3} \mathrm{H}\right]$ thymidine incorporation was also obtained at 48 and $72 \mathrm{~h}$ after the addition of vanadate (Fig. $1 e$ ), although the increase was lower than that observed at $24 \mathrm{~h}(24 \mathrm{~h}, 5.2$-fold; $48 \mathrm{~h}, 3.8$-fold; $72 \mathrm{~h}, 1.9$ fold). To demonstrate that the increased $\left[{ }^{3} \mathrm{H}\right]$ thymidine incorporation into DNA in response to vanadate represents cell proliferation, we determined the effect of vanadate on the growth rate of mesangial cells. Treatment of cells in serum-free medium with vanadate for $2 \mathrm{~d}$ increased the cell number significantly as compared with untreated controls $(40.270 \pm 574$ per well versus $31.800 \pm 1837$ per well, $P<0.01$ )

Vanadate inhibits PTPase activity and stimulates tyrosine phosphorylation. Although vanadate is a potent PTPase inhibitor in certain cells, a correlation of PTPase inhibition in response to vanadate with biologic effects has not been demonstrated in the same cell. We therefore determined the effect of vanadate on tyrosine phosphatase activity in mesangial cells. A time course experiment showed that maximal PTPase inhibition was obtained at $30 \mathrm{~min}$ after the addition of vanadate $(7.5 \mu \mathrm{M})$ to the cells (Fig. $2 a$ ). When tyrosine-phosphorylated MBP was used as substrate, PTPase activity was inhibited at concentrations as low as $1 \mu \mathrm{M}$ vanadate and a significant inhibition was observed at $10 \mu \mathrm{M}$ (Fig. $2 \mathrm{~b}$ ). Treatment of mesangial cells with vanadate also inhibited PTPase activity when an alternative substrate, RCML, was used (data not shown). It is noteworthy that induction of mitogenesis and inhibition of PTPase activity by vanadate occur at the same dose range. We next tested the effect of inhibition of PTPase activity by vanadate on protein tyrosine phosphorylation. Total cell lysates of control and vana- 

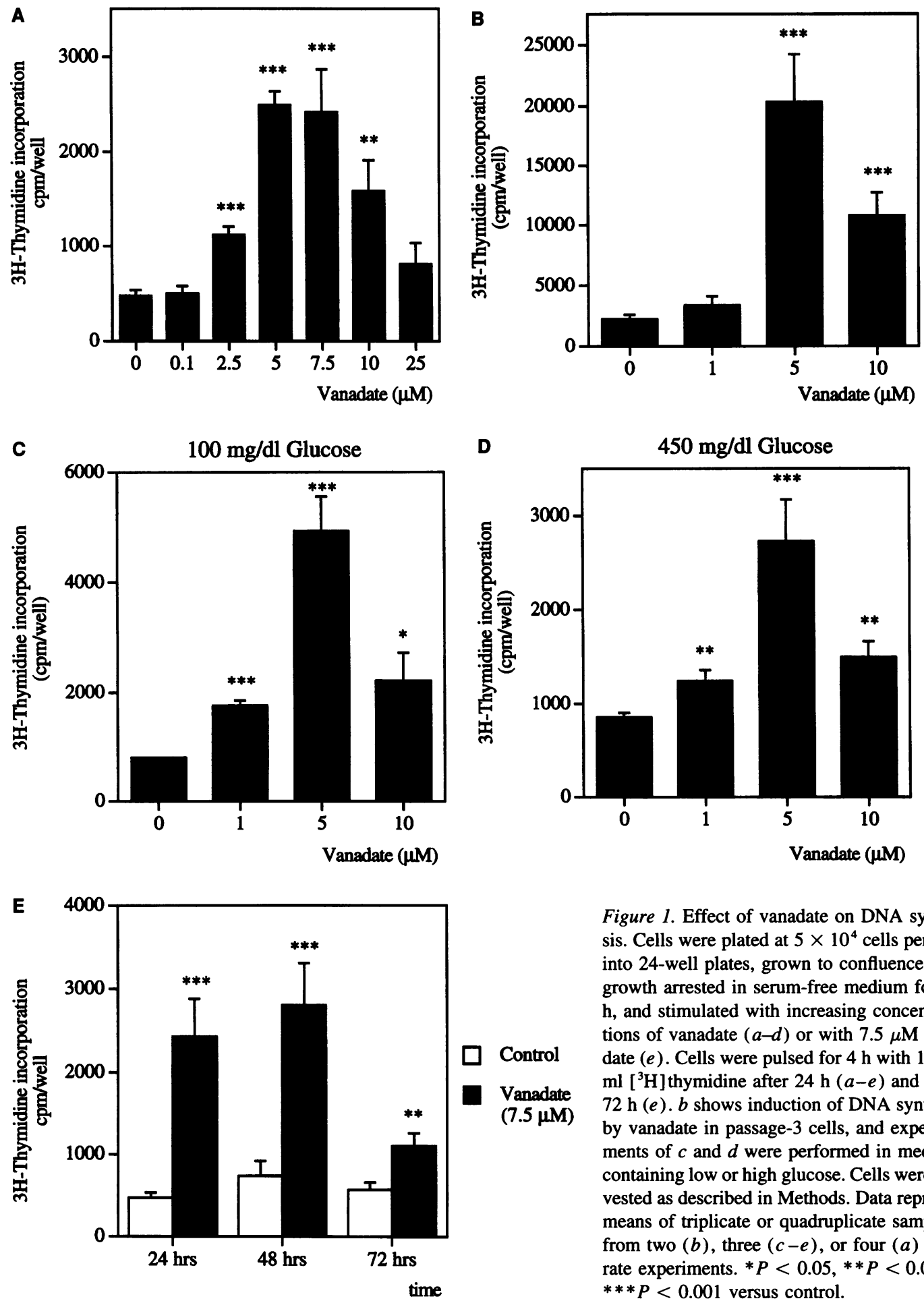

Figure 1. Effect of vanadate on DNA synthesis. Cells were plated at $5 \times 10^{4}$ cells per well into 24-well plates, grown to confluence, growth arrested in serum-free medium for 48 $\mathrm{h}$, and stimulated with increasing concentrations of vanadate $(a-d)$ or with $7.5 \mu \mathrm{M}$ vanadate $(e)$. Cells were pulsed for $4 \mathrm{~h}$ with $1 \mu \mathrm{Ci} /$ $\mathrm{ml}\left[{ }^{3} \mathrm{H}\right]$ thymidine after $24 \mathrm{~h}(a-e)$ and 48 or $72 \mathrm{~h}(e) . b$ shows induction of DNA synthesis by vanadate in passage- 3 cells, and experiments of $c$ and $d$ were performed in medium containing low or high glucose. Cells were harvested as described in Methods. Data represent means of triplicate or quadruplicate samples from two $(b)$, three $(c-e)$, or four $(a)$ separate experiments. ${ }^{*} P<0.05,{ }^{*} P<0.01$, $* * * P<0.001$ versus control.

date-treated cells were analyzed by immunoblotting using an anti-phosphotyrosine mAb. The results show that a 30-min treatment with vanadate stimulates tyrosine phosphorylation of a panel of cellular proteins (Fig. 3).

Involvement of tyrosine phosphorylation in vanadate-induced cell proliferation. Activation of tyrosine kinases by vanadate has been shown in other cell types $(26,27)$, but it is not clear whether this response is functionally linked to mitogenesis. The use of specific tyrosine kinase inhibitors is a valuable tool

to study the involvement of tyrosine phosphorylation in specific biologic processés. To determine the role of tyrosine kinase activation in vanadate-induced mitogenesis in human mesangial cells, we studied the effect of two specific PTK inhibitors, herbimycin A and genistein. Both compounds are chemically different and have different modes of action $(15,16)$. Preincubation of mesangial cells with either inhibitor blocked vanadate-induced DNA synthesis (Fig. 4, $a$ and $b$ ); 0.025\% DMSO vehicle had no effect on DNA synthesis. These results indicate that 

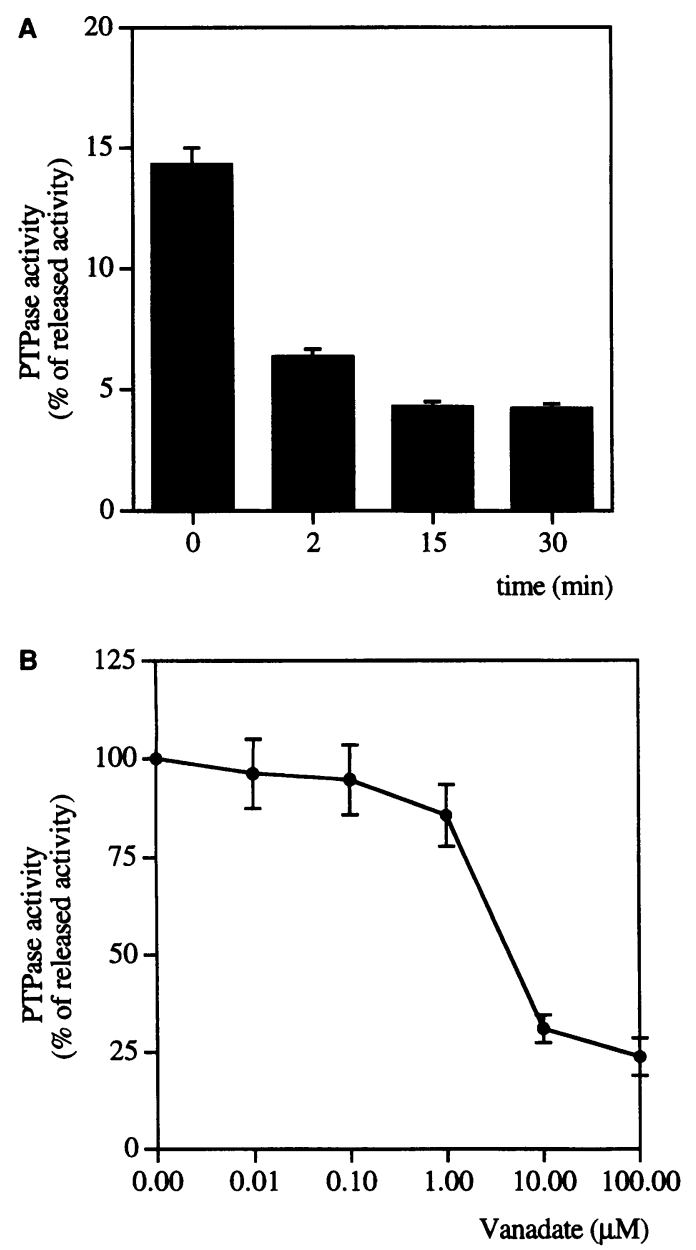

Figure 2. Inhibition of PTPase activity by vanadate. Quiescent human mesangial cells were incubated with $7.5 \mu \mathrm{M}$ vanadate for different time periods $(a)$ or with different concentrations of vanadate for $30 \mathrm{~min}(b)$. $0.5 \mu \mathrm{g}$ of cell lysate was assayed for PTPase activity using tyrosinephosphorylated MBP as substrate as described in Methods. Data represent five separate experiments, each assayed in duplicate samples.

tyrosine phosphorylation is necessary for vanadate-induced DNA synthesis.

Effect of vanadate on PDGF B chain gene expression. We have previously reported that human mesangial cells express very low levels of PDGF B chain mRNA (14). However, potent mitogens, including peptide growth factors, phorbol ester, and certain lipids that activate mesangial cells, stimulate PDGF B chain gene expression in human mesangial cells $(18,28)$. We therefore tested the effect of vanadate on PDGF B chain mRNA levels. Because of the low levels of PDGF B chain mRNA in human mesangial cells, we used an RNase protection assay to measure mRNA levels. A representative kinetic analysis of PDGF $B$ chain mRNA expression in response to vanadate is shown in Fig. 5. The data show that the PDGF B chain expression was maximal at $6 \mathrm{~h}$ and was significantly increased even at $24 \mathrm{~h}$ after the addition of vanadate.

Effect of vanadate on PLC and intracellular calcium. Tyrosine phosphorylation events are often associated with PLC activation. To determine whether PLC is activated by treatment of mesangial cells with vanadate, we determined the effect of vanadate on accumulation of $\mathrm{IP}_{3}$. Vanadate caused a significant

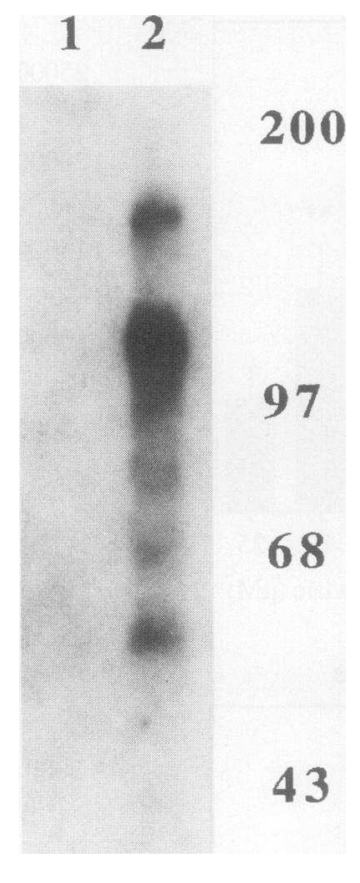

Figure 3. Stimulation of tyrosine phosphorylation by vanadate in human mesangial cell. Quiescent cells were incubated with $7.5 \mu \mathrm{M}$ vanadate for $30 \mathrm{~min}$. Cells were then gently washed with icecold PBS and lysed in solubilization buffer. After centrifugation and protein determination, equal amounts of untreated and vanadate-treated cell lysates were analyzed on a $7.5 \%$-SDS gel. Separated proteins were transferred to nitrocellulose and immunoblotted with anti-phosphotyrosine mAb. Lane 1 , unstimulated; lane 2, stimulated. Molecular weight markers are in kilodaltons.

increase in $\mathrm{IP}_{3}$ production, which was detected with a peak effect at $30 \mathrm{~min}$ (Fig. 6). This response of $\mathrm{IP}_{3}$ is similar to the $\mathrm{IP}_{3}$ response of certain growth factors with tyrosine kinase receptors $(29,30)$. To test the functional significance of this $\mathrm{IP}_{3}$ production, we next studied the effect of vanadate on intracellular calcium release in mesangial cells. Fig. 7 shows that vanadate stimulates intracellular mobilization of calcium ions and that this effect is sustained, unlike the effect of other growth factors in which calcium mobilization is a transient event. This pattern of calcium release may be related to the sustained accumulation of $\mathrm{IP}_{3}$. These data indicate that vanadate results in a rather sustained activation of early signal transduction pathways in human mesangial cells.

Effect of vanadate on PKC. The stimulation of phosphatidylinositol 4,5-bisphosphate hydrolysis to produce $\mathrm{IP}_{3}$ is associated with concomitant release of diacylglycerol (DAG), a physiological activator of PKC. Mesangial cells were incubated with $7.5 \mu \mathrm{M}$ vanadate, and PKC activity was measured after partial purification of cell lysates. As shown in Fig. 8, vanadate stimulated PKC activity 1.5-fold over basal. Downregulation of PKC by prolonged preincubation of cells with PMA abolished the increase in PKC activity in response to PMA or vanadate. Mitogenesis in response to some but not all stimuli is dependent on PKC activation. We have recently demonstrated that mitogenesis in response to PDGF is associated with and partially dependent on PKC activation in human mesangial cells $(18,23)$. PMA also stimulates DNA synthesis in these cells (18). To determine whether PKC activation is necessary for vanadateinduced mitogenesis, we studied the effect of downregulation of PKC on vanadate-induced DNA synthesis. Mesangial cells were chronically treated with PMA to downregulate PKC. Completeness of downregulation was tested by studying PMA-induced PKC activity (Fig. 8) and DNA synthesis, both of which were abrogated after PMA pretreatment. As shown in Fig. 9, chronic treatment of cells with PMA also abolished vanadateinduced DNA synthesis. These data indicate that mitogenic signals generated by vanadate are dependent on PKC activation. 

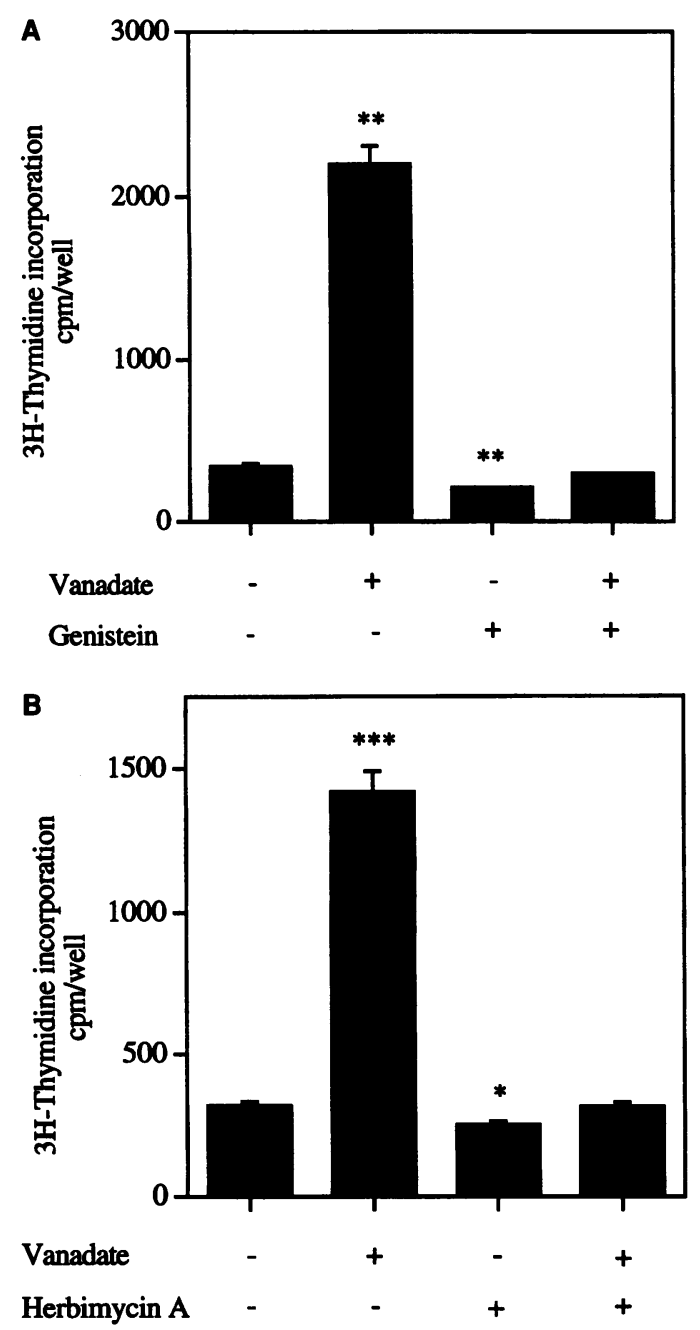

Figure 4. Effect of PTK inhibitors on DNA synthesis stimulated by vanadate. Quiescent mesangial cells were preincubated with $12.5 \mu \mathrm{M}$ genistein for $30 \mathrm{~min}(a)$ or with $0.5 \mu \mathrm{M}$ herbimycin A for $16 \mathrm{~h}(b)$ before the addition of vanadate. After $24 \mathrm{~h}$, cells were pulsed for $4 \mathrm{~h}$ with $\left[{ }^{3} \mathrm{H}\right]$ thymidine and harvested. Both PTK inhibitors blocked the increase in $\left[{ }^{3} \mathrm{H}\right]$ thymidine induced by vanadate. Data are mean \pm SEM from four independent experiments done in triplicate $(a)$ and from one experiment done in quadruplicate $(b) .{ }^{*} P<0.05, * * P<0.01,{ }^{* * *} P$ $<0.001$ versus control.

\section{Discussion}

Vanadate has insulinomimetic effects in vitro in isolated adipocytes and in vivo in animal models of diabetes. In streptozotocin-treated diabetic rats and in mouse models of non-insulindependent diabetes mellitus, treatment with vanadate has a beneficial effect, resulting in reduction of blood glucose levels and correction of several of the metabolic abnormalities $(1,2)$. These studies prompted the evaluation of vanadate as a therapeutic adjunct to insulin for the treatment of diabetes mellitus in humans $(31,32)$. The mechanism by which vanadate is thought to potentiate the effect of insulin is not precisely known. However, inhibition of tyrosine phosphatases that dephosphorylate the insulin receptor substrate and sustain its biologic activity is thought to be the major underlying mechanism. Inhibition of PTPases by vanadate has been recognized as positive and negative regulator of signal transduction $(33-35)$. Therefore, vana-

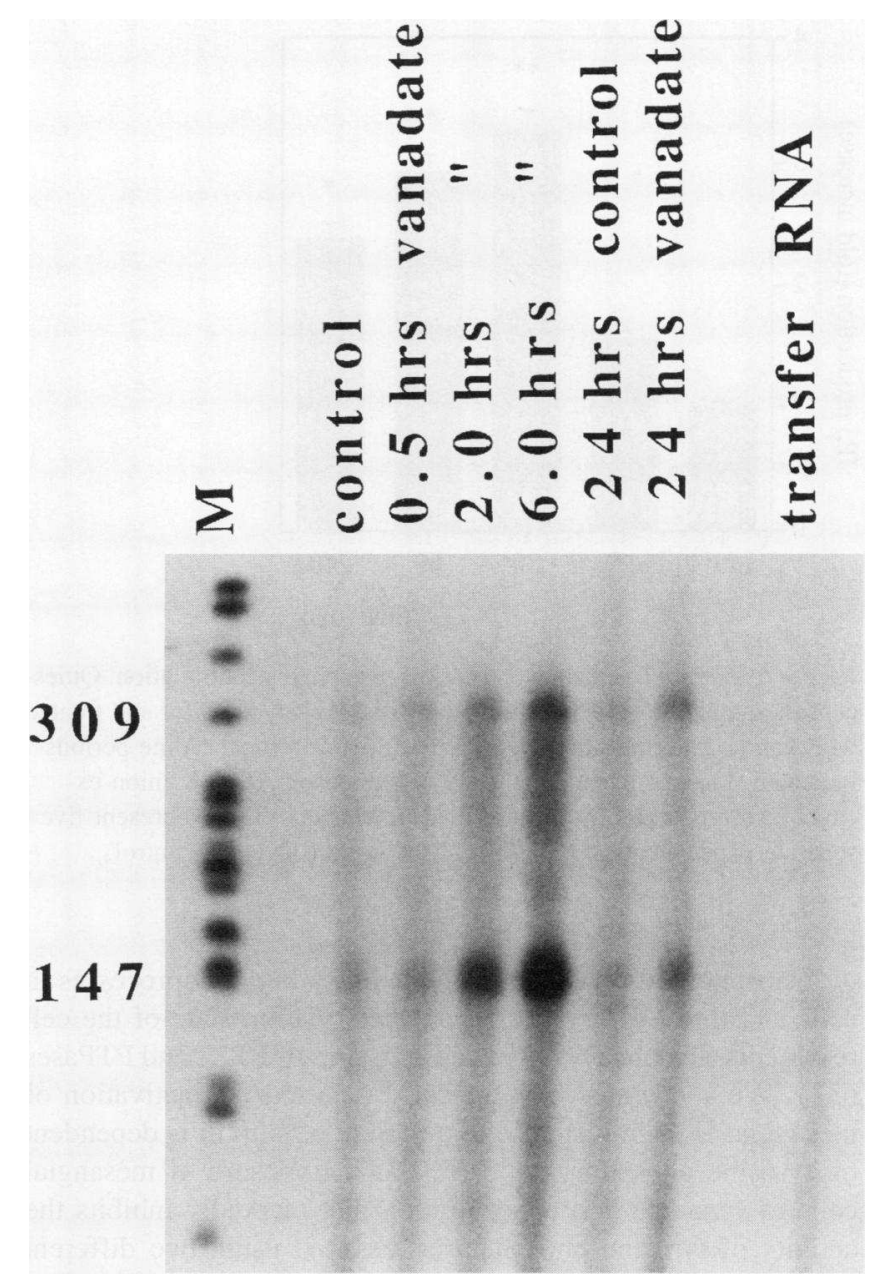

Figure 5. Time course for the effect of vanadate on PDGF B chain mRNA. Confluent cells were made quiescent in serum-free medium before exposure to vanadate. At the times indicated, cells were harvested and RNA was isolated. $100 \mu \mathrm{g}$ of total RNA or control transfer RNA was hybridized with an in vitro-transcribed labeled RNA. After digestion with RNase A and T1, protected fragments were electrophoresed on a denaturating polyacrylamide gel and detected by autoradiography. Bands shown of 300 and 150 nucleotides correspond to those portions of the sixth and seventh exons of the c-sis probe that were protected from RNase digestion. Stimulation was also observed in two other experiments.

date may exert its biologic effect in a cell- or tissue-specific manner. Nephropathy, a major complication of diabetes mellitus, is characterized by mesangial cell activation with development of mesangial matrix expansion, mesangial cell hypertrophy, and proliferation $(4,5)$. Since vanadate administered in vivo is concentrated in the kidney $(32,36)$, renal cells may be particularly susceptible to the effects of vanadate. We therefore examined the biologic effects of vanadate on cultured human mesangial cells. Our study demonstrates that vanadate at concentrations that inhibit PTPases activates mesangial cells, resulting in increased DNA synthesis, cell proliferation, and induction of PDGF B chain gene expression. These effects of vanadate are associated with increased tyrosine phosphorylation and with activation of PLC and PKC. Furthermore, DNA synthesis in response to vanadate is dependent on tyrosine kinase and PKC activation. 


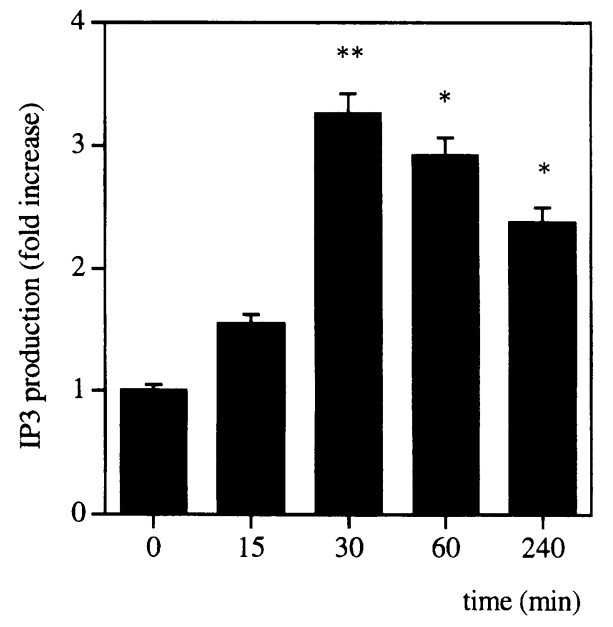

Figure 6. Effect of vanadate on inositol phosphate accumulation. Quiescent mesangial cells were prelabeled with $\left[{ }^{3} \mathrm{H}\right]$ myoinositol and treated with vanadate in the presence of $\mathrm{LiCl}(15 \mathrm{mM})$ for the time periods indicated. Inositol phosphates were separated by AGIX8 anion exchange chromatography as described in Methods. Data represent five separate experiments. $* P<0.01, * * P<0.001$ versus control.

Phosphorylation events regulate many biologic processes in cells and tissue. The tyrosine phosphorylation state of the cell represents a balance between the activities of PTKs and PTPases (37). We and others have recently reported that activation of mesangial cells in response to a variety of stimuli is dependent on tyrosine phosphorylation $(38,39)$. Exposure of mesangial cells to vanadate at a concentration that markedly inhibits the activity of tyrosine phosphatases, assayed using two different substrates, resulted in sustained mitogenesis, as measured by $\left[{ }^{3} \mathrm{H}\right]$ thymidine uptake, autoradiography, and cell counts. This effect of vanadate is associated with increased tyrosine phosphorylation of a set of cellular proteins. To investigate the role of tyrosine kinases in mediating the mitogenic effect of vanadate in human mesangial cells, we used two tyrosine kinase inhibitors: genistein and herbimycin A. Both compounds inhibited vanadate-induced DNA synthesis at concentrations known to

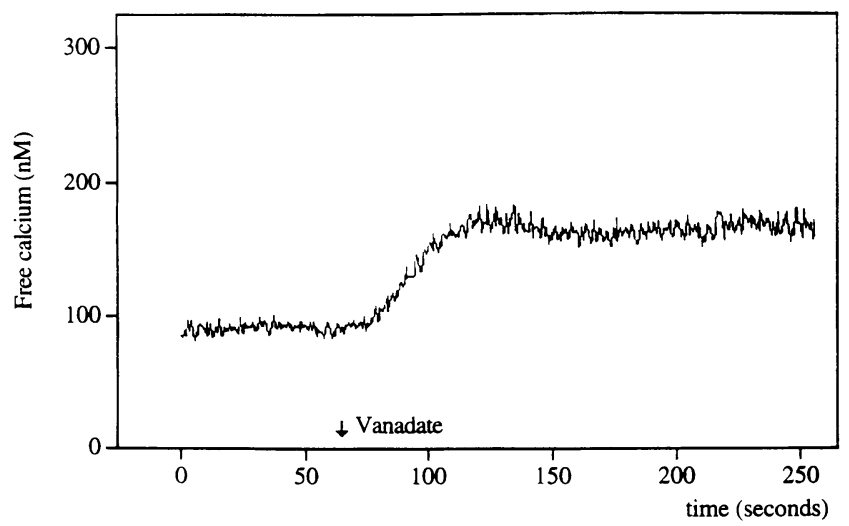

Figure 7. Time course for the effect of vanadate on cytosolic free calcium. After $18 \mathrm{~h}$ in serum-free medium, cells were loaded with fura2 as described in Methods. Vanadate was injected into the assay chamber at the time indicated by the arrow to a final concentration of $7.5 \mu \mathrm{M}$. Intracellular free calcium was measured as described in Methods.

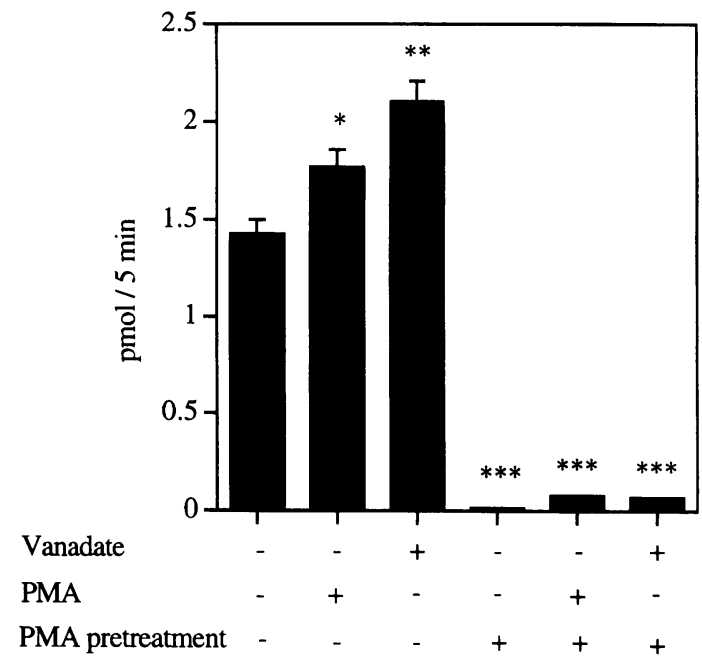

Figure 8. Effect of vanadate on PKC activity in glomerular mesangial cells. Confluent cells were made quiescent by incubation in serum-free medium in the absence or presence of $0.6 \mu \mathrm{M}$ PMA ( PMA pretreatment) for $48 \mathrm{~h}$. Cells were then subjected to no addition, $0.1 \mu \mathrm{M}$ PMA, or $7.5 \mu \mathrm{M}$ vanadate for $15 \mathrm{~min}$. PKC activity was measured as described in Methods. Each value is the mean of triplicate determinations. $* P<$ $0.05, * * P<0.01, * * * P<0.001$ versus control.

inhibit specifically the activity of tyrosine kinases in cells including mesangial cells $(15,16)$. Activation of certain tyrosine kinases may result in induction of DNA synthesis by several mechanisms. Tyrosine phosphorylation of several protein substrates occurs in response to many mitogens whose receptors either are tyrosine kinases or are linked to G-proteins. PLC $\gamma$ 1, which hydrolyses phosphatidylinositol 4,5-bisphosphate to generate $\mathrm{IP}_{3}$ and DAG, may be activated by vanadate. Treatment of mesangial cells with vanadate resulted in increased $\mathrm{IP}_{3}$ gener-

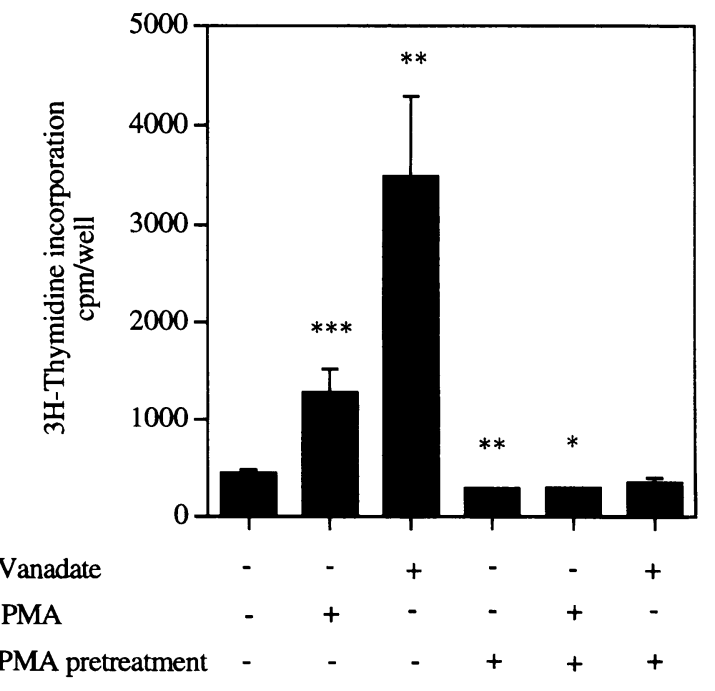

Figure 9. Effect of downregulation of PKC on DNA synthesis. Downregulation of PKC by pretreatment with $0.6 \mu \mathrm{M}$ PMA for $48 \mathrm{~h}$ blocked vanadate-induced $\left[{ }^{3} \mathrm{H}\right]$ thymidine uptake. PKC downregulation is also confirmed by the failure of fresh PMA $(0.1 \mu \mathrm{M})$ to induce DNA synthesis in PMA-pretreated cells. Results are the mean \pm SEM from three independent experiments done in triplicate or quadruplicate. ${ }^{*} P<0.05$, $* * P<0.01, * * * P<0.001$ versus control. 
ation and a sustained increase in cytosolic calcium concentration, indicating PLC $\gamma$ activation. DAG, the physiologic activator of PKC, is intimately involved in cell growth. We have recently shown that PMA is a mitogen for human mesangial cells (18), indicating that PKC may play an important role in proliferation of mesangial cells (23). However, the relative importance of PKC activation seems to differ with different mitogens and cell types (40). Vanadate treatment of mesangial cells resulted in activation of $\mathrm{PKC}$, which appears to play a crucial role in vanadate-induced mitogenesis since downregulation of total PKC activity by prolonged incubation with PMA abolished this effect of vanadate. Although both PTK and PKC have been implicated in signal transduction in response to vanadate, the precise contribution of each signaling pathway to the biologic effects of vanadate was unclear. Our data clearly indicate that mitogenesis in response to vanadate is dependent not only on tyrosine phosphorylation, but also on PKC activation. Vanadate is known to be a potent inhibitor of the $\left(\mathrm{Na}^{+} \mathrm{K}^{+}\right)$ATPase. However, this mechanism is unlikely to contribute to the observed effects of vanadate in mesangial cells since vanadate inhibits $\left(\mathrm{Na}^{+} \mathrm{K}^{+}\right)$-ATPase in purified membrane preparations but is much less potent in intact cells $(41,42)$.

Although extrapolation from in vitro to in vivo studies should be cautious, our data may have implications relevant to the use of vanadate as a therapeutic modality for diabetes. Activation of mesangial cells with subsequent proliferation and matrix expansion leads to glomerular impairment and eventual fibrosis $(43,44)$. Induction of PDGF B chain may be responsible for phenotypic changes in mesangial cells in the diabetic microenvironment. Besides its mitogenic activity, PDGF may mediate collagen synthesis induced by glycosylated proteins in mesangial cells (45). Studies in experimental models of renal injury revealed that cell proliferation occurs with concomitant upregulation of PDGF and its receptors (45-48). More recently, increased expression of several cytokines with tyrosine kinase receptors has been demonstrated in isolated glomeruli a few weeks after the induction of diabetes (49). These cytokines may be responsible for activation of mesangial cells. More importantly, potentiation of the effect of these cytokines by vanadate in vivo may potentially contribute to the progression of glomerular injury. This is particularly important since vanadate in most instances will be administered well after the diabetic state has ensued. Vanadate also activates mesangial cells even when they are maintained in relatively normal glucose concentration, suggesting that potential deleterious effects of vanadate may be detected even when hyperglycemia is controlled. It is important to note that whereas very high concentrations of vanadate $(0.5-1 \mathrm{mM})$ are required to activate the insulin receptor kinase and to mimic the metabolic effect of insulin, much lower concentrations of vanadate $(1-10 \mu \mathrm{M})$ are sufficient to inhibit PTPase activities, as shown in this study $(27,50)$. Our in vitro observations warrant in vivo studies to address further the biologic effect and potential deleterious role of vanadate on the course of diabetic nephropathy.

\section{Acknowledgments}

The authors acknowledge Kathleen Woodruf, Sergio Garcia, and Jeff Hendison for expert technical help.

This work was supported in part by the VA Medical Research Service, National Institutes of Health grants DK-33665 and DK-43988, and a Grant in Aid from the American Heart Association, Texas Affiliate.
U. O. Wenzel is supported by the Deutsche Forschungsmeinschaft. Bruno Fouqueray was supported by a grant from Foundation Pour La Recherche Medicale, France.

\section{References}

1. Heyliger, C. E., A. G. Tahiliani, and T. H. McNeil. 1985. Effect of vanadate on elevated blood glucose and depressed cardiac performance in diabetic rats. Science (Wash. DC). 227:1474-1476.

2. Meyerovitch, J., P. Rothenberg, Y. Shechter, S. Bonner-Weir, and C. R. Kahn. 1991. Vanadate normalizes hyperglycemia in two mouse models of noninsulin-dependent diabetes mellitus. J. Clin. Invest. 87:1286-1294.

3. Michael, F., M. F. Cicirelli, N. K. Tonks, C. D. Diltz, J. E. Weiel, E. H. Fisher, and E. G. Krebs. 1990. Microinjection of a protein-tyrosine-phosphatase inhibits insulin action in Xenopus oocytes. Proc. Natl. Acad. Sci. USA. 87:55145518.

4. Mauer, M. 1994. Structural-functional correlations of diabetic nephropathy. Kidney Int. 45:612-622.

5. Young, B., R. Johnson, C. Alpers, E. Eng, J. Floege, and W. Couser. 1992. Mesangial cell proliferation precedes development of glomerulosclerosis in experimental diabetic nephropathy. J. Am. Soc. Nephrol. 3:770a. (Abstr.)

6. Abboud, H. E. 1992. Growth factors and the mesangium. J. Am. Soc. Nephrol. 2:S185-S189.

7. Montesano, R., M. S. Pepper, P. Belin, J. D. Vassalli, and L. Orci. 1988. Induction of angiogenesis in vitro by vanadate, an inhibitor of phosphotyrosine phosphatases. J. Cell. Physiol. 134:460-466.

8. Canalis, E. 1985. Effect of sodium vanadate on deoxyribonucleic acid and protein synthesis in cultured rat calvariae. Endocrinology. 116:855-862.

9. Smith, J. B. 1983. Vanadium ions stimulate DNA synthesis in Swiss mouse 3T3 and 3T6 cells. Proc. Natl. Acad. Sci. USA. 80:6162-6166.

10. Maher, P. A. 1992. Stimulation of endothelial cell proliferation by vanadate is specific for microvascular endothelial cells. J. Cell. Physiol. 151:549-554.

11. Wice, B., J. Milbrandt, and L. Glaser. 1987. Control of muscle differentiation in $\mathrm{BC}_{3} \mathrm{H} 1$ cells by fibroblast growth factor and vanadate. J. Biol. Chem. 262:1810-1817.

12. Rawson, C., C. Cosola-Smith, and D. Barnes. 1990. Death of serum-free mouse embryo cells caused by epidermal growth factor deprivation is prevented by cycloheximide, 12-O-tetradecanoylphorbol-13-acetate, or vanadate. Exp. Cell Res. 186:77-181.

13. Heldin, C. H., T. Asplund, D. Ytterberg, and S. Thein. 1992. Characterization of the molecular mechanism involved in the deprivation of hyaluronan synthetase in platelet-derived growth factor in human mesothelial cells. Biochem. J. 283:165-170.

14. Shultz, P. G., P. E. DiCorleto, B. G. Silver, and H. E. Abboud. 1988 Mesangial cells express PDGF mRNAs and proliferate in response to PDGF. Am. J. Physiol. 255:F674-F684.

15. Akiyama, T., and H. Ogawara. 1991. Use and specifity of genistein as inhibitor of protein-tyrosine kinases. Methods Enzymol. 201:362-369.

16. Ueharay, Y., and H. Fuhazawa. 1991. Use and selectivity of herbimycin A as inhibitor of protein-tyrosine kinases. Methods Enzymol. 201:370-379.

17. Jaffer, F., C. Saunders, P. Schultz, D. Throck-Morton, E. Winshell, and H. E. Abboud. 1989. Regulation of mesangial cell growth by polypeptide mitogens. Inhibiting role of transforming growth factor beta. Am. J. Pathol. 135:261269.

18. Knauss, T. C., F. E. Jaffer, and H. E. Abboud. 1990. Phosphatidic acid modulates DNA synthesis, phospholipase $\mathrm{C}$ and platelet derived growth factor mRNAs in cultured mesangial cells. Role of protein kinase C. J. Biol. Chem. 265:14457-14463.

19. Streuli, M., N. X. Krueger, T. Thai, M. Tang, and H. Saito. 1990. Distinct functional roles of the two intracellular phosphatase like domains of the receptor linked protein tyrosine phosphatases LCA and LAR. EMBO (Eur. Mol. Biol. Org.) J. 9:2399-2407.

20. Ghosh Choudhury, G., V. L. Sylvia, L. M. Wang, T. Pierce, and A. Y. Sahaguchi. 1991. The kinase insert domain of colony stimulating factor-1 receptor is dispensable for CSF-1 induced phosphatidylcholine hydrolysis. FEBS ( Fed. Eur. Biochem. Soc.) Lett. 282:351-354.

21. Grandaliano, G., P. Biswas, G. Ghosh Choudhury, and H. E. Abboud. 1993. Simvastatin inhibits PDGF-induced DNA synthesis in human mesangial cells. Kidney Int. 44:503-508.

22. Grynkiewicz, G., M. Poenie, and R. Y. Tsien. 1985. A new generation of $\mathrm{Ca}^{++}$indicator with greatly improved fluorescence properties. J. Biol. Chem. 260:3440-3450.

23. Ghosh Choudhury, G., P. Biswas, G. Grandaliano, and H. E. Abboud 1993. Involvement of protein kinase $C$ in platelet-derived growth factor-mediated mitogenic signalling in human glomerular mesangial cells. Am. J. Physiol. 265:F634-F642.

24. Bell, R. M., Y. Hannun, and C. Loomis. 1986. Mixed micelle assay of protein kinase C. Methods Enzymol. 124:353-359. 
25. Yasuda, I., A. Kishimoto, S. Tanaka, M. Tominaga, A. Sakurai, and Y. Nishizuka. 1990. A synthetic peptide substrate for selective assay of protein kinase C. Biochem. Biophys. Res. Commun. 166:1220-1227.

26. Brown, D. J., and J. A. Gordon. 1984. The stimulation of pp60 visrc kinase activity by vanadate in intact cells accompanies a new phosphorylation state of the enzyme. J. Biol. Chem. 259:9580-9586.

27. Tamura, S., T. A. Brown, J. H. Whipple, Y. Fujita-Yamaguchi, R. E. Dubler, K. Cheng, and J. Larner. 1984. A novel mechanism for the insulin-like effect of vanadate on glycogen synthase in rat adipocytes. J. Biol. Chem. 259:6650-6658.

28. Silver, B. G., F. E. Jaffer, and H. E. Abboud. 1989. Platelet derived growth factor (PDGF) synthesis in mesangial cells: induction by multiple peptide mitogens. Proc. Natl. Acad. Sci. USA. 86:1056-1060.

29. Abboud, H. E., G. Grandaliano, M. Pinzani, T. Knauss, G. F. Pierce, and F. Jaffer. 1994. Action of platelet-derived growth factor isoforms in mesangial cells. J. Cell. Physiol. 158:140-150.

30. Escobedo, J. A., and L. T. Williams. 1988. A PDGF receptor domain essential for mitogenesis but not for many other responses to PDGF. Nature (Lond.). 335:85-87.

31. Shechter, Y. 1990. Insulin-mimetic effects of vanadate. Possible implications for future treatment of diabetes. Diabetes. 39:1-5.

32. Cros, G., J. J. Mongold, J. J. Serrano, S. Ramanadham, and J. H. McNeill. 1992. Effects of vanadyl derivatives on animal models of diabetes. Mol. Cell. Biochem. 109:163-166.

33. Bosch, F., M. Hatzoglou, E. A. Park, and R. W. Hanson. 1990. Vanadate inhibits expression of the gene for phosphoenolpyruvate carboxykinase (GTP) in rat hepatoma cells. J. Biol. Chem. 265:13677-13682.

34. Wu, Y. Y., and R. A. Bradshaw. 1993. Effect of nerve growth factor and fibroblast growth factor on PC12 cells: inhibition by orthovanadate. J. Cell Biol. 121:409-422.

35. Klarlund, J. K. 1985. Transformation of cells by an inhibitor of phosphatases acting on phosphotyrosine in proteins. Cell. 41:707-717.

36. Saxena, A. K., P. Srivastava, R. K. Kale, and N. Z. Baquer. 1992. Effect of vanadate administration on polyol pathway in diabetic rat kidney. Biochem. Int. 26:59-68.

37. Fischer, E. H., H. Charbonneau, and N. K. Tonks. 1991. Protein tyrosine phosphatases: a diverse family of intracellular and transmembrane enzymes. Science (Wash. DC). 253:401-406.

38. Grandaliano, G., G. Ghosh Choudhury, P. Biswas, and H. E. Abboud.
Mitogenic signalling of thrombin in mesangial cell: role of tyrosine phosphorylation. Am. J. Physiol. 267:F528-F536.

39. Ghosh Choudhury, G., P. Biswas, G. Grandaliano, B. Fouqueray, S. A. Harvey, and H. E. Abboud. 1994. PDGF-mediated activation of phosphatidylinositol 3 kinase in human mesangial cells. Kidney Int. 46:37-47.

40. Huang, C. L., and H. E. Ives. 1987. Growth inhibition by protein kinase $\mathrm{C}$ late in mitogenesis. Nature (Lond.). 329:847-850.

41. Dubyak, G. R., and A. Kleinzeller. 1980. The insulin-mimetic effects of vanadate in isolated rat adipocytes. Dissociation from effects of vanadate as a $\left(\mathrm{Na}^{+}-\mathrm{K}^{+}\right)$-ATPase inhibitor. J. Biol. Chem. 255:5306-5312.

42. Nechay, B. R. 1984. Mechanisms of action of vanadate. Annu. Rev. Pharmacol. Toxicol. 24:501-524.

43. Striker, G. E., E. P. Peten, M. A. Carome, C. M. Pesce, K. Schmidt, C. W. Yang, S. J. Elliott, and L. J. Striker. 1993. The kidney disease of diabetes mellitus (KDDM): a cell and molecular biology approach. Diabetes Metab. Rev. 9:3756.

44. Sharma, K., and F. N. Ziyadeh. 1993. The transforming growth factorbeta system and the kidney. Semin. Nephrol. 13:116-128.

45. Doi, T., H. Vlassara, M. Kirstein, Y. Yamada, G. E. Striker, and L. J. Striker. 1992. Receptor-specific increase in extracellular matrix production in mouse mesangial cells by advanced glycosylation end products is mediated via platelet-derived growth factor. Proc. Natl. Acad. Sci. USA. 89:2873-2877.

46. Barnes, J. L., and H. E. Abboud. 1993. Temporal expression of autocrine growth factors corresponds to morphological features of mesangial proliferation in habu snake venom induced glomerulonephritis. Am. J. Pathol. 143:1366-1367.

47. Gesualdo, L., M. Pinzani, J. J. Floriano, M. O. Hassan, N. U. Nagy, F. P. Schena, S. N. Emancipator, and H. E. Abboud. 1991. Platelet-derived growth factor expression in mesangial proliferative glomerulonephritis. Lab. Invest. 64:160-167.

48. Iida, H., R. Seifert, C. E. Alpers, R. G. K. Gronwald, P. E. Phillips, P. Pritzl, K. Gordon, A. M. Gown, R. Ross, D. F. Bowen-Pope, and R. J. Johnson. 1991. Platelet-derived growth factor (PDGF) and PDGF receptor are induced in mesangial proliferative nephritis in the rat. Proc. Natl. Acad. Sci. USA. 88:65606564.

49. Nakamura, T., M. Fukui, I. Ebihara, S. Osada, I. Nagaoka, Y. Tomino, and H. Koide. 1993. mRNA expression of growth factors in glomeruli from diabetic rats. Diabetes. 42:450-456.

50. Gherzi, R., C. Caratti, G. Andraghetti, S. Bertolini, A. Montemurro, G. Sesti, and R. Cordera. 1988. Direct modulation of insulin receptor protein tyrosine kinase by vanadate and anti-insulin receptor monoclonal antibodies. Biochem. Biophys. Res. Commun. 152:1474-1480. 